\title{
An adolescent with both Wegener's Granulomatosis and chronic blastomycosis
}

\author{
Reem Abdwani*1, Kristin Houghton ${ }^{2}$, Simon Dobson ${ }^{3}$, Maureen O' Sullivan ${ }^{4}$ \\ and Peter Malleson ${ }^{2}$
}

Address: ${ }^{1}$ Division of Child health, Sultan Qaboos University Hospital, Muscat, Oman, ${ }^{2}$ Division of Pediatric Rheumatology, University of British Columbia, Vancouver, Canada, ${ }^{3}$ Division of Infectious Disease, University of British Columbia, Vancouver, Canada and ${ }^{4}$ Department of Pathology \& Laboratory Medicine, University of British Columbia, Vancouver, Canada

Email: Reem Abdwani* - reemabd@hotmail.com; Kristin Houghton - khoughton@cw.bc.ca; Simon Dobson - sdobson@cw.bc.ca; Maureen O' Sullivan - mo'sullivan@cw.bc.ca; Peter Malleson - pmalleson@cw.bc.ca

* Corresponding author

Published: 3 August 2008

Pediatric Rheumatology 2008, 6:13 doi:10.1186/1546-0096-6-13

This article is available from: http://www.ped-rheum.com/content/6/1/13

(c) 2008 Abdwani et al; licensee BioMed Central Ltd.

This is an Open Access article distributed under the terms of the Creative Commons Attribution License (http://creativecommons.org/licenses/by/2.0), which permits unrestricted use, distribution, and reproduction in any medium, provided the original work is properly cited.

Received: 12 January 2008

Accepted: 3 August 2008

\begin{abstract}
We report a case of Wegener's Granulomatosis (WG) associated with blastomycosis. This appears to be the first case report of WG co-existing with a tissue proven blastomycosis infection. The temporal correlation of the two conditions suggests that blastomycosis infection (and therefore possibly other fungal infections), may trigger the systemic granulomatous vasculitis in a predisposed individual; a provocative supposition warranting further study.
\end{abstract}

\section{Introduction}

Wegener's Granulomatosis is a systemic small vessel vasculitis of unknown etiology, associated with the presence of anti-neutrophil cytoplasmic antibodies ANCA usually C-ANCA directed against Proteinase 3 (PR-3). It is postulated that auto-immune and infectious mechanisms play a role in the pathogenesis [1]. Viral, bacterial and fungal infections have been reported in association with ANCA positive vasculitis. The presence of infection suggests that pathogens may act as potential triggers of an inflammatory cascade ultimately resulting in vascular inflammation [2]. We report a case of WG that may have been triggered by blastomycosis. To our knowledge, this is the first reported case of such an association.

\section{Case presentation}

A 16 year old previously healthy girl presented with a 3 day history of progressive pain and swelling in the right calf with inability to bear weight. On further questioning, she also complained of arthralgias, myalgias for the past month with history of intermittent chest pain in the absence of cough or dyspnea for the previous 3 months. In addition, she had generalized constitutional symptoms of generalized fatigue and malaise for the past 2 weeks. She had no history of fever, night sweats weight loss, rash, ocular, ear, nose, throat, gastrointestinal or genitourinary. These symptoms occurred 3 months following a 2 week travel to Kenora, Ontario. Physical examination was unremarkable, with the exception of a swollen warm and exquisitely tender right calf.

A Computerized Tomography (CT) scan of the chest and an ultrasound Doppler of right leg were performed because of concern of deep vein thrombosis (DVT) and pulmonary embolism. Chest CT showed a $3 \mathrm{~cm}$ cavitary lesion in the left upper lobe with surrounding consolidation (figure 1). Ultrasound Doppler showed no evidence of DVT. Acute phase reactants were elevated: ESR $56 \mathrm{~mm} /$ 


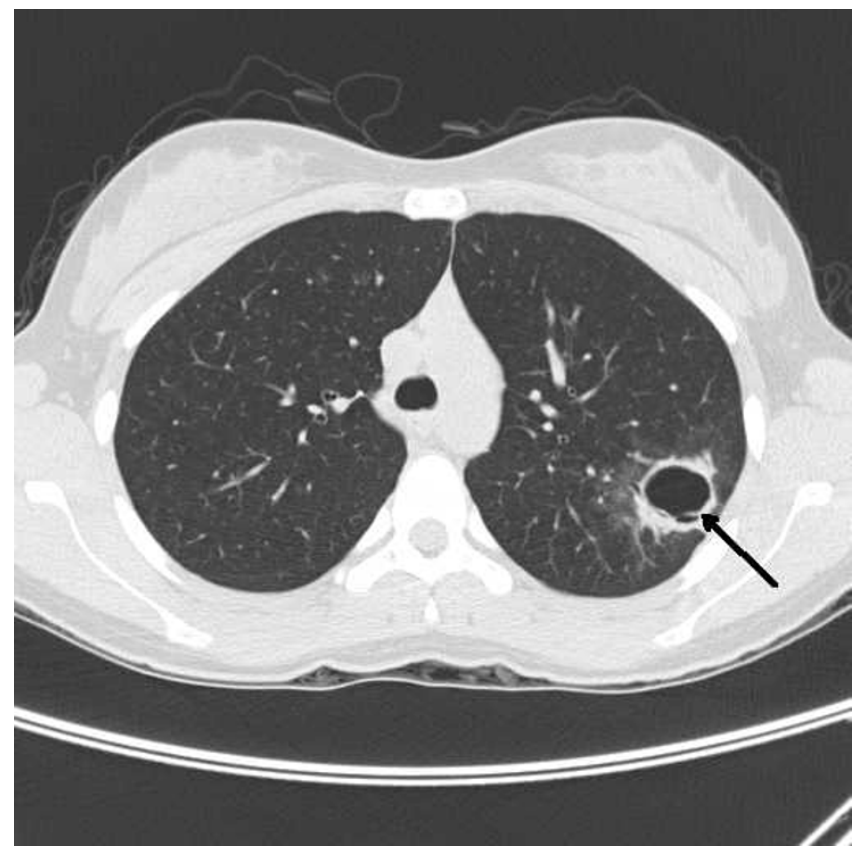

Figure I

Chest CT showed a $3 \mathrm{~cm}$ cavitary lesion in the left upper lobe with surrounding consolidation.

$\mathrm{hr}$ and $\mathrm{C}$ reactive protein $60 \mathrm{mg} / \mathrm{l}$. Urinalysis showed trace protein and $9 \mathrm{RBC} / \mathrm{HPF}$ with no urinary sedimentation or casts. Other initial investigations including a complete blood count, liver enzymes and creatinine kinase were normal. The initial working diagnosis was a pulmonary infection with a septic embolus in the calf musculature. The patient was treated with broad spectrum antibiotics with rapid resolution of the calf pain and swelling.

However, although she improved, she continued to have migrating polymyalgias, arthralgias and intermittent trace hematuria prompting investigations for an underlying rheumatic disease. Antinuclear antibodies including antidouble stranded DNA, and anti-extractable nuclear antigens were all negative. However, C-ANCA was positive by immunoflurescence and PR3 titer by ELSIA was strongly positive at 94 (positive levels $>30$ ). suggestive of a diagnosis of WG. Because there was a recent travel history to Kenora, Ontario, a region with a high incidence of blastomycosis, a bronchoscopy and an open lung biopsy were preformed. The lung biopsy revealed fungal yeast forms compatible with blastomycosis, and changes of necrotizing granulomatous inflammation and vasculitis compatible with WG. The extent of the necrotizing granulomatous disease and the necrotizing vasculitis, seemed more than would be expected with blastomycosis alone.

Because of the concern that immunosuppressive therapy might lead to disseminated blastomycosis, and as there remained some question that blastomycosis alone could explain all her symptoms and laboratory findings it was elected to initially treat her with the anti-fungal agent Itraconazole alone. With this treatment there was some improvement in chest pain and the radiographic findings, but she continued to have myalgias, arthralgias, intermittent trace hematuria and persistent elevation in acute phase reactants and anti-PR3 levels. She also developed episcleritis and epistaxis. A kidney biopsy showed mildly active pauci-immune proliferative glomerulonephritis. Based on the additional system involvement the diagnosis of WG was felt to be confirmed, so after 4 months of Itraconazole, she was started on prednisone $(1 \mathrm{mg} / \mathrm{kg} /$ day $)$ and cyclophosphamide $(2 \mathrm{mg} / \mathrm{kg} /$ day $)$ with rapid improvement in her symptoms and normalization of acute phase reactants. The anti-PR3 levels also became negative.

\section{Discussion}

Blastomycosis is a rare but potentially fatal infection by the fungus Blastomycosis dermatitidis. Blastomycosis is endemic in the united states around Mississippi and Ohio River basins, and Midwestern states, Canadian provinces bordering the great lakes and small areas bordering the St. Lawrence River, and Manitoba. Hyperendemicity in the region surrounding Kenora, Ontario have recently been reported with an annual incidence rate of 117.2 per 100,000 population [3]. Children account for $2-11 \%$ of cases $[4,5]$.

The initial clinical presentation of blastomycosis includes fever, malaise, weight loss, cough and pleuritic chest pain. Cutanous lesions and less commonly bone, genitourinary and central nervous system involvement can occur. Most cases of acute blastomycosis are self-limited [6], but the mortality rate of untreated chronic blastomycosis approaches $60 \%$ [7]. The diagnosis is made by demonstration of the organism in the lesions. Most experts advocate specific targeted antifungal therapy for all cases of blastomycosis. Itraconazole is the drug of choice for patients with blastomycosis that is not life threatening, and does not involve the central nervous system. Amphotericin B is reserved for those with severe life threatening disease, central nervous system involvement and immunocompromised patients.

WG is a rare multisystem disorder, characterized by necrotizing granulomatous inflammation and pauci-immune small vessel vasculitis [8]. The triad of paranasal sinus involvement, pulmonary infiltration and renal involvement is characteristic. Up to $90 \%$ of children with WG have initial upper airway symptoms [9], such as nasal discharge, sinusitis, or epistaxis. Lower respiratory symptoms occur in $74 \%$ of children with WG [9], symptoms include cough, dyspnea, and hemoptysis. Nodular and cavitating 
lung lesion are often visible on radiographs. Renal disease occurs in $61 \%$ of children with WG [9] and often leads to renal failure. Disease of the skin (purpura, vesicles, papules, and nodules);CNS (cranial nerve palsy, seizures and peripheral neuropathy); heart (myocardial infarction, arrhythmia, and valvulitis); and eyes (scleritis, episcleritis, dacrocystitis, and corneal ulcers) may occur.

The diagnosis of WG can be difficult; tissue diagnosis of necrotizing granulomatous inflammation is the gold standard. The diagnosis is supported by the presence of CANCA (anti-PR3). Although C-ANCA has a high specificity $90-95 \%[10,11]$, it has been reported in patients with infections such as HIV, CMV Mycobacterium avium-intercellulare, invasive amebiasis, Bartonella Henessae, and Malaria. [12-18]. A positive C-ANCA can also occur in connective tissue diseases such as systemic lupus erythematosus and rheumatoid arthritis [19], as well as other vasculitides including microscopic polyangitis and ChurgStrauss syndrome [20]. Accordingly, many authorities feel that neither the presence of a positive C-ANCA nor positive PR3 antibodies should be used to replace a tissue biopsy in confirming the diagnosis of WG.

In our patient, the clinical picture of malaise, weight loss, myalgia, arthralgia, cavitating and nodular lung lesions, microscopic hematuria, episcleritis, nasal crusting and epistaxis supported by the finding of a positive C-ANCA suggested the diagnosis of WG. Open lung biopsy confirmed the diagnosis of blastomycosis and the histology was strongly suggestive of a co-existing granulomatous vasculitis. Although granulomatous changes in tissues can certainly occur with blastomycosis the extent of the vascular changes were felt to be more than could be explained by blastomycosis alone.

Although, there has been other reports of ANCA associated vasculitis triggered by fungal infection $[21,22]$, as far as we can ascertain this is the first report of WG co-existing with tissue proven blastomycosis infection. The temporal correlation of the symptoms suggests that the fungal infection may have triggered the systemic vasculitis. The other possible explanation could be given the very high incidence of blastomycosis in Kenora region in Ontario, a patient with evolving WG could contract blastomycosis.

The unusual association of blastomycosis and WG raises the intriguing possibility that infections, particularly those in which granulomata formation occurs, may be one of the triggers for WG in the predisposed host [23]. Epidemiological evidence to support this hypothesis is presently lacking. There has been anecdotal (albeit unpublished) evidence that there was a recent increase in the occurrence of WG in children in several areas of North America, suggesting perhaps that infection can be a trigger for WG in children. The recent development of a pediatric Wegener's registry by the Childhood Arthritis and Rheumatology Research Alliance (CARRA) will hopefully allow the accrual of epidemiologic evidence that will help confirm or refute this possibility.

\section{Competing interests}

The authors declare that they have no competing interests.

\section{Authors' contributions}

$\mathrm{RA}, \mathrm{KH}$ and PM were involved in patient care and in drafting the manuscript. SD was involved in infectious disease aspect of patient care. MS was involved in the pathologyrelated portion of the manuscript.

All authors read and approved the final manuscript.

\section{Consent}

Consent for publication was obtained from the relatives (parents) of the patient.

\section{References}

I. Lynch JP, White E, Tazelaar H, Langford CA: Wegener's granulomatosis: evolving concepts in treatment. Semin resp and critical care med 2004, 25:491-521.

2. Watts RA, Scott DG: Secondary vasculitis and vasculitis mimics. In Oxford Textbook of Rheumatology 3rd edition. Edited by: Isenberg DA, Maddision PJ, Woo P, glass D, Breedveld FC. Oxford; 2005:963-968.

3. Wolfgang L: Clinical features of primary ANCA- associated vasculitis. In Oxford Textbook of Rheumatology 3rd edition. Edited by: Isenberg DA, Maddision PJ, Woo P, glass D, Breedveld FC. Oxford; 2005:943-963.

4. Morris SK, Brophy J, Richardson SE, Parkin PC, Jamieson F, Limerick $B$, Wiebe L, Ford- Jones EL: Blastomycosis in Ontario, 19942003. Emerg Infect Dis 2006, I 2(2):274-279.

5. Steele RW, Abernathy RS: Systemic blastomycosis in children. Pediatr Infect Dis 1983, 2(4):304-307.

6. Schutze GE, Hickerson SL, Fortin EM, Schellhase DR, Darville T, Gubbins PO, Jacobs RF: Blastomycosis in children. Clinical Infectious Diseases 1996, 22:496-502.

7. Sarosi GA, Davies SF, Phillips JR: Self-limited blastomycosis: a report of 39 Cases. Seminars in Respiratory Infections 1986, I:40-44.

8. Chapmann SW: Blastomycosis dermatidis. In Textbook of Principles and practice of infectious diseases 5th edition. Edited by: Mandell GL, Nennet JE, Dolin R. New York: Churchill Livingstone; 2000:2733-2746.

9. Rottem M, Fauci AS, Hallahan CW, Kerr GS, Lebovics R, Leavitt RY, Hoffman GS: Wegener granulomatosis in children and adolescents: clinical presentation and outcome. Journal of Pediatrics 1993, I 22:26-31.

10. Gross WL, Schmitt WH, Csernok E: Antineutrophil cytoplasmic autoantibody- associated diseases: a rheumatologist's perspective. Am J Kidney Dis I99I, I 8(2): I75-179.

II. Gross WL, Schmitt WH, Csernok E: ANCA and associated diseases: immunodiagnostic and pathogenetic aspects. Clin Exp Immunol 1993, 91(I): I-12.

12. Cornely OA, Hauschild S, Weise C, Csernok E, Gross WL, Salzberger B, Fatkenheuer G, Diehl V, Schrappe M: Seroprevalence and disease association of antineutrophil cytoplasmic autoantibodies and antigens in HIV infection. Infection 1999, 27:92-96.

13. Meyer MF, Hellmich B, Kotterba S, Schatz H: Cytomegalovirus infection in systemic necrotizing vasculitis: causative agent or opportunistic infection? Rheumatol International 2000, 20:35-38.

14. Chaiamnuay S, Heck LW: Antineutrophil cytoplasmic antibody vasculitis associated with mycobacterium avium intracellulare infection. Journal of Rheumatology 2005, 32:1610-1612. 
15. Adebajo AO, Charles PJ, Hazleman BL, Maini RN: Antineutrophil cytoplasmic antibody titers in patients with recent infection. British Journal of Rheumatology 1993, 32:941-942.

16. Pudifin D, Duursma J, Garhiram V: Invasive ameobiasis is associated with the development of antineutrophil cytoplasmic antibody. Clin Exp Immunol 1994, 97( I):48-5I.

17. Fukushima $H$, Numaga J, Yoshimoto M, Kato S, Kawashima H: An ocular cat scratch disease patient positive for cytoplasmic anti-neutrophil cytoplasmic antibody. Graefes Archives of Clinical and Experimental Ophthalmology 200I, 239:882-885.

18. Pradhan V, Badakere SS, Shankarkumar U, lyer YS, Ghosh K, Karnad $D$ : Anti-neutrophil cytoplasmic antibodies (ANCA) in malaria. Indian Journal of Malariology 2002, 39:5I-59.

19. Savige JA, Gallicchio MC, Stockman A, Cunningham TJ, Rowley MJ, Georgiou T, Davies D: Antineurtrophil cytoplasmic antibodies in rheumatoid arthritis. Clinical \& Experimental Immunology 1991, 86:92-98.

20. Gross WL, Schmitt WH, Csernock E: ANCA and associated diseases: immunodiagnostic and pathogenetic aspects. Clin Exp Immunol 1993, 91(I):I-I2.

21. Kon Y, Bohgaki M, Notoya A, Mukai M, Kohno M, Sato H: Microscopic polyangitis triggered by fungal infections. Hokkaido Igaku Zasshi 2006, 8I:5-8.

22. Stappaerts I, Bogers J, Ebo D, Vanden Broecke E, Stevens WJ, Van Marck E, Vermeire P: c -ANCA positivity in a Belgian patient with pulmonary paracoccidioidomycosis. European Respiratory Journal 1997, 10:2419-2422.

23. Lamprecht $P$, Csernok E, Gross WL: Effector memory $\mathbf{T}$ cells as driving force of granuloma formation and autoimmunity in Wegener's granulomatosis. Journal of Internal Medicine 2006, 26:|87-|9|.

Publish with Bio Med Central and every scientist can read your work free of charge

"BioMed Central will be the most significant development for disseminating the results of biomedical research in our lifetime. "

Sir Paul Nurse, Cancer Research UK

Your research papers will be:

- available free of charge to the entire biomedical community

- peer reviewed and published immediately upon acceptance

- cited in PubMed and archived on PubMed Central

- yours - you keep the copyright 